Review

\title{
Soy and Breast Cancer: Focus on Angiogenesis
}

\section{Lenka Varinska ${ }^{1}$, Peter Gal ${ }^{1,2,3,4}$, Gabriela Mojzisova ${ }^{5}$, Ladislav Mirossay ${ }^{1}$ and Jan Mojzis ${ }^{1, *}$}

1 Department of Pharmacology, P.J. Šafárik University, Faculty of Medicine, Trieda SNP 1, 04011 Košice, Slovakia; E-Mails: lenka.varinska@upjs.sk (L.V.); peter.gal@upjs.sk (P.G.); ladislav.mirossay@upjs.sk (L.M.)

2 Department for Biomedical Research, East-Slovak Institute of Cardiovascular Diseases, Ondavská 8, 04011 Košice, Slovakia

3 Department of Pharmacognosy and Botany, Faculty of Pharmacy, Commenius University, Odbojárov 10, 83210 Bratislava, Slovakia

4 Institute of Anatomy, 1st Faculty of Medicine, Charles University, U nemocnice 3, 12800 Prague, Czech Republic

5 Department of Experimental Medicine, P.J. Šafárik University, Faculty of Medicine, Trieda SNP-1, 04011 Košice, Slovakia; E-Mail: gabriela.mojzisova@upjs.sk

* Author to whom correspondence should be addressed; E-Mail: jan.mojzis@upjs.sk; Tel./Fax: +421-55-234-3485.

Academic Editor: Sanjay K. Srivastava

Received: 19 February 2015 / Accepted: 8 May 2015 / Published: 22 May 2015

\begin{abstract}
Epidemiological studies have revealed that high consumption of soy products is associated with low incidences of hormone-dependent cancers, including breast and prostate cancer. Soybeans contain large amounts of isoflavones, such as the genistein and daidzain. Previously, it has been demonstrated that genistein, one of the predominant soy isoflavones, can inhibit several steps involved in carcinogenesis. It is suggested that genistein possesses pleiotropic molecular mechanisms of action including inhibition of tyrosine kinases, DNA topoisomerase II, 5 $\alpha$-reductase, galectin-induced $\mathrm{G}_{2} / \mathrm{M}$ arrest, protein histidine kinase, and cyclin-dependent kinases, modulation of different signaling pathways associated with the growth of cancer cells (e.g., NF- $\mathrm{B}$, Akt, MAPK), etc. Moreover, genistein is also a potent inhibitor of angiogenesis. Uncontrolled angiogenesis is considered as a key step in cancer growth, invasion, and metastasis. Genistein was found to inhibit angiogenesis through regulation of multiple pathways, such as regulation of VEGF, MMPs, EGFR expressions and NF- $\mathrm{BB}, \mathrm{PI} 3-\mathrm{K} / \mathrm{Akt}$, ERK1/2 signaling pathways, thereby
\end{abstract}


causing strong antiangiogenic effects. This review focuses on the antiangiogenic properties of soy isoflavonoids and examines their possible underlying mechanisms.

Keywords: soy; genistein; breast cancer; angiogenesis; galectins

\section{Introduction}

Breast cancer is the second most frequently diagnosed cancer and the leading cause of death among woman in developed countries, accounting for $22 \%$ of new cases each year [1]. Data from human studies have shown great differences in breast cancer incidence among woman with Western lifestyles (e.g., United States and Western Europe) and woman from Asia (e.g., Japan and Chinese) [2]. Results from epidemiological studies suggest that diet may strongly contribute to this variation in the breast cancer prevalence [3-5]. One possible explanation of this phenomenon is a high consumption of soy foods in Asia [6]. It is suggested that in Asian countries the average daily intake of soy isoflavones is 25-50 mg [7], while in the U.S. and Europe is less than $1 \mathrm{mg}$ [8]. Ability of soy to reduced risk of breast cancer in Chinese women was for the first time documented by Lee and coworkers [9]. So far, several epidemiologic studies evaluating the relation between soy intake and breast cancer incidence has been conducted in the world [10-14]. Although all of these studies had some limitations, it is generally accepted that high soy intake is associated with reduced risk of breast cancer in Asian women.

Soybeans contain several constituents able to modulate carcinogenesis, namely initiation, promotion and cancer progression $[15,16]$. Among them, genistein and other phytoestrogens attract great interest, as they exhibit a plethora of biological actions, including breast and prostate cancer chemopreventive activity [17-21].

It is well known that many risk factors for breast cancer are related to prolonged exposure to estrogen and other hormones. Furthermore, most breast cancers are hormone-receptor-positive [22]. Soy phytoestrogens, such as genistein, daidzein, and glycitein, are isoflavonoids closely related to human 17 $\beta$-estradiol [23], but with lower estrogenic activity [24]. Genistein has been identified as the predominant isoflavone in soybean. It possesses biphasic effect on estrogen receptor (ER) positive breast cancer cells. At low concentrations, it stimulates growth of ER positive breast cancer cells, whereas at higher concentrations growth of breast cancer cells is inhibited [25,26]. Apart from its estrogenic/antiestrogenic activity, genistein inhibits also growth of hormone non-dependent cancer cells [27,28]. Based on available experimental data, it is suggested that genistein can influence mechanisms involved in cell proliferation and possesses pleiotropic molecular mechanisms of action. Genistein is a well-known RTKs inhibitor, which may prevent abundant cell proliferation or abnormal angiogenesis by inhibiting receptor-associated tyrosine kinases (RTK)-mediated signaling pathways [29]. Furthermore, genistein inhibits DNA topoisomerase II activity [30] and is able to suppress its expression [31]. Soy isoflavonoids exert different anti-cancer mechanisms: (i) inhibition of $5 \alpha$-reductase, protein histidine kinase, and cyclin-dependent kinases [32-35]; (ii) decrease the signaling pathways associated with the growth of cancer cells (e.g., NF-кB, Akt, MAPK); and (iii) apoptosis induction [36]. 
Taken together, genistein and other soy isoflavonoids exhibit multiple effects on the human malignant cells and also modulate selected steps of angiogenesis.

\section{Angiogenesis and Breast Cancer}

During embryonic development, endothelial progenitor cells (angioblasts) form a primitive vascular network of small capillaries in a process termed "vasculogenesis". Subsequent vessel sprouting (angiogenesis) from pre-existing vessels results in the creation of arteries and veins [37]. Angiogenesis is not temporally restricted to embryonic development, but is also active under specific physiological conditions in healthy adults. This process is regulated by a wide range of angiogenic inducers (e.g., growth factors, chemokines, angiogenic enzymes, endothelial-specific receptors, and adhesion molecules) as well as various endogenous angiogenesis inhibitors, like angiostatin, endostatin, thrombospondin, and canstatin. Imbalances between the angiogenic inducers and inhibitors may result in pathologies, such as arthritis, psoriasis, obesity, asthma, atherosclerosis, heart and brain ischemia, neurodegeneration, hypertension, pre-eclampsia, respiratory distress, osteoporosis, and many other disorders [38]. Angiogenesis has also been recognized as a basic prerequisite for progression, proliferation and metastatic spread of tumors.

During tumorigenesis, most tumors start growing as avascular nodules to a certain size not exceeding a few millimeters. This first phase in tumor expansion is followed by the switch from avascular to vascular phenotypes due to the malignant tissue hypoxia and malnutrition. The onset of the "angiogenic switch" is a discrete step in the development of malignant tumors that is inevitable for growth and metastasis [39]. Although it has been recognized for many centuries that neoplastic tissue is more vascular than its normal counterpart, it is only since Folkmans' hypothesis on anti-angiogenesis that extensive research in the regulation of angiogenesis has started [40]. The vascular endothelial growth factor (VEGF) family represents the most important component in the angiogenic pathway [41]. The most intensively studied member of VEGF family is VEGF-A. It is considered the most important regulator in human physiologic and pathologic angiogenesis and high levels of circulating VEGF are a well-established indicator of poor prognosis in several cancers, including breast cancer $[42,43]$. A monoclonal antibody designed against VEGF-A (bevacizumab) was the first U.S. Food and Drug Administration (FDA)-approved anti-angiogenic drug.

Despite showing efficacy in some cancer types (such as metastatic colorectal cancer or non-squamous non-small cell lung cancer), conflicting results about the benefit of VEGF blockade have been obtained in advanced breast cancer [44]. The E2100 phase III study demonstrated that the combination of bevacizumab with paclitaxel was shown to result in superior progression-free survival (PFS) and increased the objective response rate compared to chemotherapy alone [45]. Based on these, data bevacizumab was approved by the European Medicines Agency (EMEA) and the FDA for the treatment of HER2-negative metastatic breast cancer when administered in combination with chemotherapy. In another three studies (AVADO, RIBBON-1, and RIBBON-2), despite the improvement in PFS and the proportion of patients achieving a response, the combination of bevacizumab and chemotherapy has so far proven disappointment in term of improving overall survival (OS) [46-48]. As a consequence of this, and increase in incidence of adverse events in bevacizumab/chemotherapy arm, the FDA withdrew its earlier approval in this indication. A new 
suggested approach how to maximize the benefit of bevacizumab and restrict tumor re-growth after anti-angiogenic drugs is sustained VEGF suppression, as it was validated in metastatic colorectal cancer [49,50]. Adherence to a maintenance therapy after first-line treatment appears to be effective also in breast cancer. TANIA study was designed to evaluate further bevacizumab in bevacizumab-pretreated locally recurrent/metastatic breast cancer [51]. The analyses of data showed a benefit from the use of bevacizumab across multiple lines of therapy. Continued bevacizumab with capecitabine statistically significant and clinically meaningful improved PFS and OS in patients benefiting from first-line bevacizumab-containing therapy what was observed in the open-label randomized phase III IMELDA trial [52]. Thus, prolonging first-line chemotherapy with maintenance treatment may influence OS.

Another angiostatic drugs, tyrosine kinase inhibitors, namely sorafenib, sunitinib, pazopanib and axitinib, have remained ineffective in treating breast cancer [53-55] despite the benefit showed in other cancers [56]. Everolimus, a small molecule inhibitor of mammalian target of rapamycin (mTOR) and recombinant human endostatin are other anti-angiogenic molecules that undergo clinical trials and might be used in treatment settings of breast cancer [57,58]. Selected clinical trials are presented in Table 1.

In conclusion, according to the present results, the role of anti-angiogenic drugs still remain unclear in breast cancer and needs further investigation. Alternative strategies, based on targeting of microRNAs, may serve as novel therapeutic targets [59]. Likewise, phytotherapy could offer many new opportunities in treating breast cancer patients. It is commonly used in many fields of medicine due to its excellent properties, such as simple preparation and administration as well as poor presence of side effects and acceptable efficiency. The use of natural products may represent a feasible option of cancer-treatment in many regions of the world. It has been shown that almost $80 \%$ of the world's population uses medicine of herbal origin for primary health care. Accordingly, the World Health Organization has also recommended natural agents as an alternative to synthetic pharmaceuticals in developed countries [60]. 
Table 1. Antiangiogenic drugs used in breast cancer treatment-clinical trials.

\begin{tabular}{|c|c|c|c|c|}
\hline Breast Cancer & Treatment & Clinical Trial & Outcame & Reference \\
\hline \multirow[t]{2}{*}{ Neoadjuvant } & doxorubicin/docetaxel/cyclophosphamide \pm bevacizumab & NCT00408408 & improvement in pCR DFS and OS-data under way & [61] \\
\hline & epirubicin-cyclophosphamide/docetaxel \pm bevacizumab & NCT00567554 & no improvement in DFS and OS improvement in pCR & {$[62,63]$} \\
\hline \multirow[t]{2}{*}{ Adjuvant } & anthracycline, taxane or both \pm bevacizumab & BEATRICE & no improvement in DFS, OS & {$[64]$} \\
\hline & adjuvant hormone therapy \pm everolimus & NCT01805271 & ongoing trial & - \\
\hline \multirow[t]{5}{*}{ First-line } & paclitaxel \pm bevacizumab & E2100 & improvement in PFS not OS & {$[45]$} \\
\hline & docetaxel \pm bevacizumab & AVADO & improvement in PFS not OS & {$[46]$} \\
\hline & $\begin{array}{l}\text { capecitabine/taxane/anthracycline based } \\
\text { chemotherapy } \pm \text { bevacizumab }\end{array}$ & RIBBON-1 & improvement in DFS not OS & {$[53]$} \\
\hline & trastuzumab, docetaxel \pm bevacizumab & AVEREL & no improvement in PFS or OS & [65] \\
\hline & Docetaxel \pm sunitinib & NCT00393939 & no improvement in PFS or OS & {$[54]$} \\
\hline $\begin{array}{l}\text { First-line/ } \\
\text { second-line }\end{array}$ & capecitabine \pm sorafenib & NCT01234337 & ongoing study & {$[66]$} \\
\hline \multirow[t]{8}{*}{ Second-line } & capecitabine \pm bevacizumab & AVF2119 & no improvement in PFS or OS & [67] \\
\hline & capecitabine \pm sunitinib & NCT00435409 & no improvement in PFS or OS & [55] \\
\hline & exemestane \pm everolimus & NCT00863655 & improvement in PFS not OS & [57] \\
\hline & trastuzumab, vinorelbine \pm everolimus & NCT01007942 & improvement in PFS, OS in progress & [68] \\
\hline & $\begin{array}{l}\text { capecitabine/taxane/gemcitabine/vinorelbine based } \\
\text { chemotherapy } \pm \text { bevacizumab }\end{array}$ & RIBBON-2 & improvement in PFS not OS & [48] \\
\hline & capecitabine $v s$. sunitinib & NCT00373113 & inferior PFS and OS for sunitinib arm & [69] \\
\hline & chemotherapy \pm bevacizumab & TANIA & improvement in PFS, OS not reported & {$[51]$} \\
\hline & bevacizumab + capecitabine bavacizumab alone & IMELDA & improvement in PFS and OS & {$[52]$} \\
\hline
\end{tabular}

pCR pathological complete response; OS overall survival; DFS disease free survival; PFS progression free survival. 


\section{Antiangiogenic Effect of Soy Isoflavonoids}

Formation of new blood vessels occurs as a result of several processes, including activation of endothelial cells, destruction of matrix by proteolytic enzymes, migration and proliferation of endothelial cells as well as formation of tubular structures [70]. Tumor angiogenesis can be inhibited by blocking some of these steps. Several papers have been published referring on the modulatory effect of flavonoids on angiogenesis [71-78]. Soy isoflavonoids also exhibit anti-angiogenic activities, but the precise mechanism of inhibition remains unclear. These compounds exert anti-angiogenic effect either directly through endothelial cells (EC) or indirectly by modulating the tumor microenvironment [79-81].

As mentioned above, VEGF is an important regulator of angiogenesis and inhibition of VEGF secretion or blockade of its receptors is associated with suppression of blood vessels formation [82]. Genistein at doses 5-50 $\mu \mathrm{M}$ prevented the growth of human umbilical vein endothelial cells (HUVECs) after stimulation with VEGF. Moreover, genistein $(10-50 \mu \mathrm{M})$ significantly inhibited basal VEGF expression and hypoxia-stimulated VEGF expression in both cancer cells and HUVECs. Expression of the VEGF receptor fms-like tyrosine kinase-1 in HUVECs was also reduced after treatment with genistein. As authors suggested, genistein may inhibit tumor angiogenesis through the suppression of VEGF-mediated signaling pathways between tumor cells and vascular endothelial cells [83]. Loss of VEGF activity under hypoxic condition after treatment with genistein may also be associated with ability of genistein to interfere with the post-transcriptional induction of VEGF by hypoxia [84]. Later, Yu and co-workers [85] studied the effect of genistein on VEGF secretion and VEGF mRNA expression in mammary cancer cells. They found that the level of VEGF protein in genistein-treated cells was significantly decreased compared with non-treated cells. Furthermore, the level of VEGF mRNA expression was consistent with the alteration of level of protein expression.

Anti-angiogenic effect of genistein has also been reported by Su and co-workers [86]. They showed a dose-dependent inhibition of expression/excretion of VEGF. Genistein also decreased VEGF mRNA expression both under normoxic and hypoxic conditions. Similarly, lower levels of VEGF mRNA were found in xenograft tumors. Moreover, activation of hypoxia inducible factor-1 (HIF-1) was impaired in cells treated with genistein under hypoxic conditions. As it is suggested, anti-angiogenic effect of genistein can be mediated by the inhibition of the HIF-1 activation with subsequent inhibition of VEGF gene expression [87]. A similar relation between VEGF and HIF-1 was also recently documented by Aditya et al. [88]. They found that treatment of cancer cells with combination of curcumin and genistein led to angiogenesis inhibition by acting on VEGF protein expression via down regulation of HIF-1 $\alpha$ and aryl hydrocarbon receptor nuclear translocator. Genistein, in addition to VEGF mRNA suppression, at a low physiological dose $(2.5 \mu \mathrm{mol} / \mathrm{L})$ also affected the levels of mRNA for VEGF receptor 1 (VEGFR-1) and 2 (VEGFR-2) in HUVECs [89]. Furthermore, in various in vivo experiments (using xenografts, chick chorioallantoic membrane or zebrafish experimental models), genistein significantly reduced microvessel density [90-92]. Moreover, other pro-angiogenic factors such as platelet-derived growth factor (PDGF), tissue factor (TF), urokinase plasminogen activator (uPA), matrix metalloproteinase-2 and -9 (MMP-2, and MMP-9) were also inhibited in genistein-treated cells [86]. On the other hand, up-regulation of anti-angiogenic factors (e.g., plasminogen activator inhibitor-1, endostatin, angiostatin, and thrombospondin-1) was observed [86]. On the contrary, no significant angiogenesis inhibition was noticed for daidzein. 
Components of the extracellular matrix (ECM) play pivotal roles in docking cells and engaging them in the complex molecular interplay. Aberrations in this complex network, either engineered in mice or detected in patients, can lead to diseases [93,94]. Constituents of the ECM have proven capable to stimulate angiogenesis [95]. Lysis of ECM is necessary to promote endothelial cell invasion and sprouting. The most relevant proteolytic enzymes involved in angiogenesis are MMP-2 and -9 and uPA-plasmin system [96-98]. Genistein can interfere with the activity of MMPs, reducing the degradation of ECM, which forms the basis of angiogenic switch. Treatment of HUVECs with $\mathrm{VEGF/bFGF} \mathrm{(basic} \mathrm{fibroblast} \mathrm{growth} \mathrm{factor)} \mathrm{caused} \mathrm{significant} \mathrm{increase} \mathrm{in} \mathrm{MMP-1} \mathrm{production} \mathrm{as} \mathrm{well}$ as induction of pro-MMP-2 activation [99]. However, pretreatment with genistein completely prevented the VEGF/bFGF-stimulated increase in both MMP-1 expression and pro-MMP-2 activation. Moreover, genistein also blocked VEGF/bFGF-induced uPA and PA inhibitor-1 expression. Later, Kumi-Diaka et al. [100] also documented inhibition of MMP-2 expression in cells treated with genistein. Additionally, genistein reduced the mRNA level of several MMPs including MMP-2, MMP-3, MMP-13, and MMP-15 [101]. However, not all studies confirmed ability of genistein to block activity of MMPs. Farina et al. [102] found no effect of genistein on MMP-2 and MMP-9 activity. On the other hand, in vivo administration of either genistein or a soy-based diet reduced tumor-induced angiogenesis in syngeneic mice implanted with B16 or F3II cells.

Recent application of genome-wide screening revealed that genistein or daidzein down-regulated a set of genes necessary for the angiogenesis pathway either in HUVECs or cancer cells. In HUVECs, Piao et al. [103] studied effect of genistein $(10.0 \mu \mathrm{mol} / \mathrm{L})$ on expression of several genes involved in cell proliferation, adhesion, transcription, translation, metabolism, cytoskeleton or apoptosis. Genistein was observed to down-regulate cell adhesion-related genes (e.g., VE-cadherin, integrin $\alpha \mathrm{V}$, connexin 43, and multimerin) on mRNA level. In the study of Rabiau et al. [104] the main result showed a down-regulation of epidermal growth factor (EGF) and insulin-like growth factor 1 (IGF-1) after treatment with genistein $(40.0 \mu \mathrm{mol} / \mathrm{L})$ or daidzein $(110.0 \mu \mathrm{mol} / \mathrm{L})$. Moreover, expression of other pro-angiogenic molecules such as cadherin 5, PDGF, VEGF, fibroblast growth factor 1 (FGF 1), MMP-9, uPA, angiopoietin 2, hepatocyte growth factor (HGF), and interleukin 18 were also significantly down-regulated in cancer cells treated with genistein or daidzein, respectively. Furthermore, genistein has also been observed to down-regulate gene expression of VEGF, uPA receptor, lysophosphatidic acid receptor [105] as well as fibronectin and MMP-13 [106].

Cancer cells are known to have alterations in multiple cellular signaling pathways. A number of studies suggest that chemopreventive effects of genistein are due to the regulation of different important cellular signaling pathways [107]. It has been accepted that nuclear factor $\kappa \mathrm{B}(\mathrm{NF}-\kappa \mathrm{B})$ signaling pathway plays an important roles in physiological as well as pathological processes such as control of cell growth, apoptosis, inflammation, invasion, transformation and angiogenesis [108]. Thus, inhibition of NF- $\kappa \mathrm{B}$ activity in cancer/endothelial cells may provide a target for cancer treatment and/or prevention. Recently, Wang et al. [109] have found that genistein suppressed MMP-9 transcription by inhibiting $\mathrm{NF}-\kappa \mathrm{B}$ activity. It suppressed 12-O-tetradecanoylphorbol-13-acetate (TPA)-induced NF- $\kappa \mathrm{B}$ - specific DNA-protein binding compared to TPA via inhibition of NF- $\mathrm{B}$ nuclear translocation through inhibitor of kappa B inhibitory signaling pathways. Moreover, genistein also suppressed TPA-induced activation of extracellular signal-regulated kinases/phosphatidylinositol 3-kinase/protein kinase B (ERK/PI3K/Akt) upstream of NF-kB. 
Furthermore, consumption of genistein significantly down-regulated cell proliferation as well as receptors for growth factors (EGFR, IGF-1R) and mitogen-activated protein kinase (MAPKs) that play a significant role in stimulating cell proliferation (ERK-1/2) in prostates of TRAMP mice [110]. Recently, $\mathrm{Yu}$ et al. [111] studied effect of genistein on VEGF-stimulated HUVECs. Genistein at concentrations $1.0-100.0 \mu \mathrm{mol} / \mathrm{L}$ effectively inhibited VEGF-induced protein tyrosine kinase stimulation. Simultaneously, levels and activity of MMP-2 and -9 were significantly suppressed in genistein-treated HUVECs. Exposure of HUVECs to genistein also reduced VEGF-mediated phosphorylation of c-Jun $\mathrm{N}$-terminal kinases (JNK) and p38. In contrast to the previous study [90], genistein did not significantly decrease endothelial cell ERK-1/2 phosphorylation. In another study, Huang et al. [112] also showed ability of genistein to inhibit MMP-2 activity as well as its ability to block activation of p38 MAPK by transforming growth factor $\beta$ (TGF- $\beta$ ). In addition to this study, genistein has been found to block TGF- $\beta$-induced activation of MMP-2 and p38 MAPK via blocking activation of the MAP kinase activated protein kinase 2 and the $27-\mathrm{kDa}$ heat shock protein a down-downstream effectors of p38 MAP kinase [113].

Prostaglandins play a key role in many of physiological as well as pathological processes. They are generated from arachidonate by the action of cyclooxygenase (COX). Cyclooxygenase-2 (COX-2), a COX isoenzyme catalyzing the production of prostaglandins, is reported to be involved in the pathogenesis of many human tumors [114,115]. Some results also indicate that COX-2 is associated with increased VEGF production and angiogenesis [116-118]. Furthermore, COX-2 has been shown to enhance bFGF-induced angiogenesis through induction of VEGF in rat sponge implants [119]. The results of Akarasereenont et al. [120] showed that COX-2 is over-expressed in HUVECs treated with VEGF. Increase in both protein level and COX-2 activity was significantly reduced when cells were co-incubated with genistein. This effect was strongly correlated with inhibition of VEGF-associated protein tyrosine kinase.

Another possible field of genistein action is cancer-related inflammation. The association between inflammation and cancer is now accepted as enabling characteristic of cancer [121]. Inflammation in the tumor microenvironment affects many aspects of malignancy. It aids in the growth and survival of malignant cells, stimulates angiogenesis and suppresses adaptive immune responses [122,123]. Prostaglandins produced by COX-2 play an important role in inflammation, thus inhibition of this COX isoform is suggested to be potential target for cancer chemoprevention/treatment [124-126]. In the study of Hwang et al. [127], the effect of genistein on TPA-induced inflammation-related signaling pathway was studied. Genistein alone or in combination with capsaicin efficiently reduced COX-2 expression in MCF-7 cells. This effect was associated with activation of AMP-activated protein kinase. Ability of genistein or daidzein to inhibit COX-2 expression as well as activation of NF- $\kappa \mathrm{B}$ in TPA treated animals was documented also by others authors [128-130].

Another important inflammatory component of the stroma of many tumors are tumor-associated macrophages (TAMs). They play a key role in tumor angiogenesis by secreting a numerous of substances that promote angiogenesis including VEGF, PDGF, TGF- $\beta$, FGF, MMP-2, MMP-7, MMP-9, MMP-12, COX-2 as well as several chemokines [131-134]. It was demonstrated that macrophage-released VEGF in solid tumors contributed to the initiation of tumor angiogenesis with an increased number of vessels and branches [135]. Thus, targeting of TAMs may represent a new strategy to complement "classical" anticancer therapy. Genistein was found to reduce the number of 
TAMs by $96 \%$ when administered to rats bearing MAT-Lu tumors. Moreover, genistein in in vitro conditions significantly suppressed tumor necrosis factors- $\alpha$ secretion and lipopolysaccharide-stimulated production of granulocyte-macrophage colony-stimulating factor, both pro-angiogenic factors [136].

Glyceollins, a novel class of soybean phytoalexins with potential cancer-preventive effects, also possesses antiangiogenic activity. Lee et al. [137] found that glyceollins in vitro inhibited VEGFR-2 and FGFR-1 activity and their downstream signaling pathways (e.g., ERK1/2, JNK). Glyceollins also significantly suppressed microvessel density in both in vivo and ex vivo conditions. Later, these authors studied effect of glyceollins on HIF-1 $\alpha$ regulation. Under hypoxic conditions they reduced the expression of HIF-1 $\alpha$ in various cancer cells by inhibiting the PI3K/AKT/mTOR pathway. This effect may also be associated with blockade of the interaction of HIF-1 $\alpha$ with $90-\mathrm{kDa}$ heat shock protein. Moreover, glyceollins inhibited the expression of HIF-1 $\alpha$-induced genes such as the VEGF. Furthermore, glyceollins were found to decrease microvessel density in solid tumor tissues [138]. Additionally to previously mentioned articles, glyceollins were documented to inhibit the transcriptional activation of COX-2 by regulating NF- $\kappa \mathrm{B}$ activity. Based on these results, it may be hypothesized that glyceollins may modulate the cancer inflammatory microenvironment [139].

\section{Do Galectins Mediate Estrogen-Dependent Signals Following Soy Consumption?}

Increasing attention is given to the role of glycosylation of proteins and lipids where the sugar-encoded information is being translated into several cellular activities by endogenous lectins [140,141]. Since galectins play an important role in the processes of cell proliferation, differentiation, migration and extracellular matrix formation $[142,143]$, it has been proven that they are significant modulators of the tumor/wound microenvironments [144]. In general, it has been shown that the main role of galectin-1 in cancer progression represents its immunosuppressive effect, which facilitates pro-tumorigenic microenvironment [145,146] and stimulates angiogenesis [147]. Similarly, over-expression of galectin-3 in hypoxic breast tumors was associated with the presence of more aggressive tumors leading to a poor prognosis [148,149]. Galectin-3 is also an important mediator of VEGF- and bFGF-mediated angiogenic response [150].

Several studies have focused on the soy compound isoflavonoid genistein and its potential chemopreventive activities in the breast cancer [151]. It was shown that galectin-1 is up-regulated in invasive breast carcinoma demonstrating a positive correlation with the TNM staging system [152]. Accordingly, silencing of galectin-1 in breast carcinoma model inhibited tumor growth and prevented metastatic disease [145]. Soy consumption reduced galectin-1 intensities in blood mononuclear cells [153]. Moreover, our results indicated that the estrogen receptor- $\alpha$ agonist increases the expression of galectin-1 in keratinocytes (unpublished data). Since long-term estradiol deprivation enhanced estrogen sensitivity in breast cancer, it may by suggested that soy consumption could overcomes tumor-associated-galectin-1-induced immunosuppression [154].

Similarly, at the cellular level, it was well demonstrated that the phytoestrogen genistein inhibits proliferation of human breast carcinoma cell lines [151]. It has been shown that the genistein-induced $\mathrm{G}_{2} / \mathrm{M}$ arrest was mediated via galectin-3 [155]. Contrary to previously published reports, this phytoestrogen acted as a key regulator in the $\mathrm{WNT} / \beta$-catenin signaling pathway [156], which led to 
endothelial cells tube-like formation on Matrigel [157]. Moreover, genistein stimulated the growth of estrogen receptor-positive breast cancer cells MCF-7 in an athymic mice xenograft model [158].

From this point of view, the intriguing relationships between estrogens and galectins need to be studied in detail to avoid complications in patient treatment. Of note, data on the relationships between other galectins and estrogens in the breast cancer and/or angiogenesis has not yet been documented. Nevertheless, data summarized in this review could have broad implications for developing novel, estrogen/carbohydrate-based therapeutic agents for inhibition of tumor growth and angiogenesis. Figure 1 summarizes the molecular targets of genistein on endothelial and cancer cells.

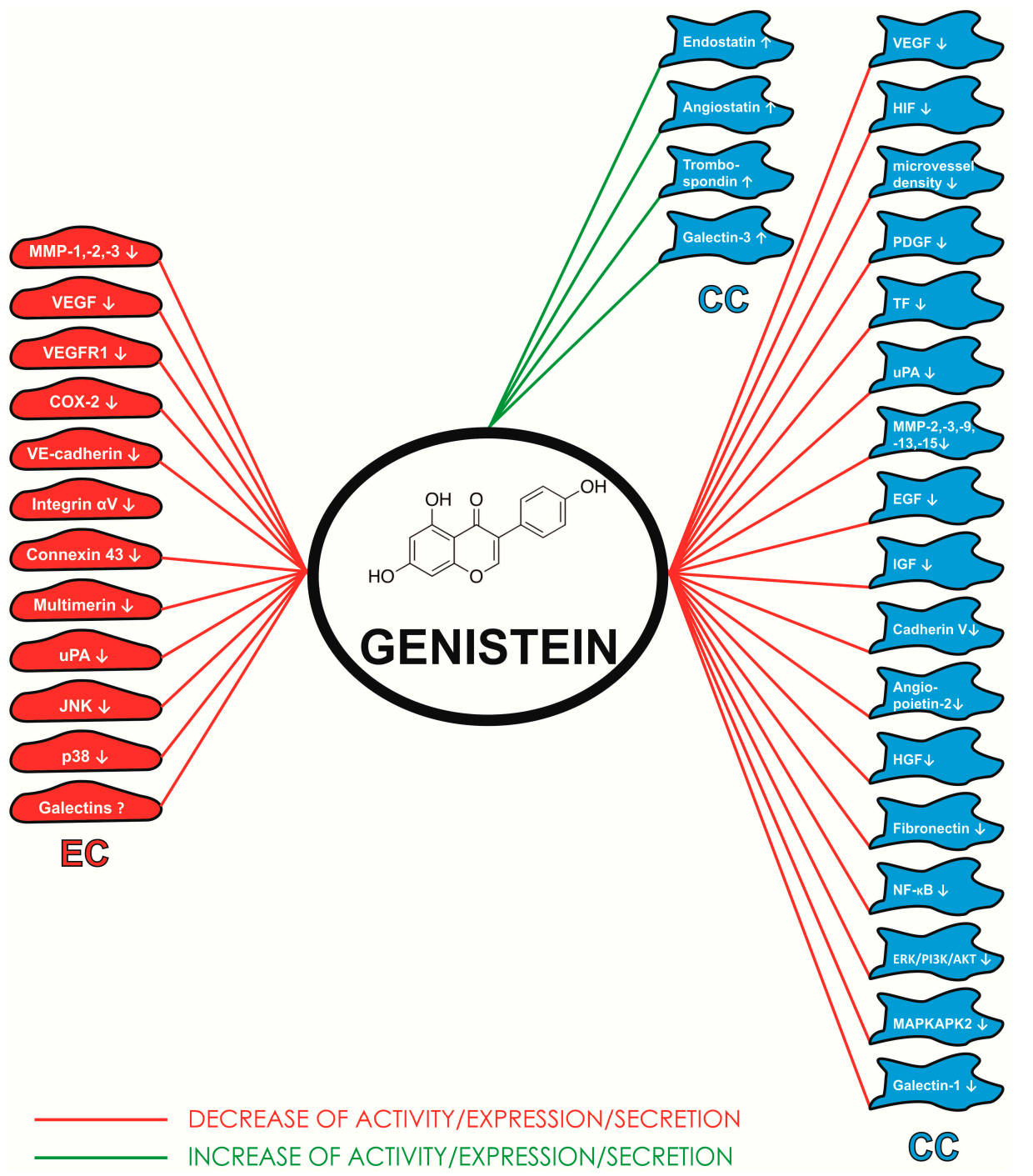

Figure 1. Molecular targets of genistein on endothelial (EC) and cancer (CC) cells. Akt-protein kinase B; bFGF-basic fibroblast growth factor; COX-2 - cyclooxygenase-2; EGF - fibroblast growth factor; ERK - extracellular signal-regulated kinases; HIF-hypoxia inducible factor; IGF — insulin-like growth factor; JNK-c — Jun $N$-terminal kinases; MAPKmitogen-activated protein kinase; MAPKAPK2-MAP kinase activated protein kinase 2; MMP-matrix metalloproteinase; NF- $\kappa \mathrm{B}$ - nuclear factor $\kappa \mathrm{B}$; PDGF-platelet-derived growth factor; TF-tissue factor; TNF- $\alpha$-tumor necrosis factors $\alpha$; uPA-urokinase plasminogen activator; VEGF — vascular endothelial growth factor; VEGFR1-receptor for vascular endothelial growth factor 1 . 


\section{Conclusions}

In conclusion, anticarcinogenic effects of soy isoflavonoids, particularly genistein, are mediated via several molecular pathways. In addition to the direct effects of isoflavonoids on cancer cells, genistein also modulates selected steps of angiogenesis namely growth and sprouting of endothelial cells, microcapillary tube formation and/or inhibition of several cell signaling pathways. In in vivo experiments, genistein-induced growth suppression of experimental tumors was also associated with significant reduction of microvessel density.

Although more studies are required to fully elucidate the mechanism of antiangiogenic action of soy isoflavones, and more clinical trials are needed to validate their usefulness in clinical practice, experimental data have shown that genistein is a promising agent for cancer chemoprevention.

\section{Acknowledgments}

This study was supported by the Slovak Research and Development Agency under the contract no. APVV-0408-12, the Grant Agency of Ministry of Education, Science, Research, and Sport of the Slovak Republic (VEGA 1/0299/13 and VEGA 1/0048/15). This study was also supported (50\%) by the project Medicínsky univerzitný park v Košiciach (MediPark, Košice) ITMS: 26220220185 (95\%) supported by Operational Programme Research and Development (OP VaV-2012/2.2/08-RO) (Contract No. OPVaV/12/2013.).

\section{Conflicts of Interest}

The authors declare no conflict of interest.

\section{References}

1. DeSantis, C.; Ma, J.; Bryan, L.; Jemal, A. Breast cancer statistics, 2013. CA Cancer J. Clin. 2014, 64, 52-62.

2. Xie, Q.; Chen, M.L.; Qin, Y.; Zhang, Q.Y.; Xu, H.X.; Zhou, Y.; Mi, M.T.; Zhu, J.D. Isoflavone consumption and risk of breast cancer: A dose-response meta-analysis of observational studies. Asia Pac. J. Clin. Nutr. 2013, 22, 118-127.

3. Shimizu, H.; Ross, R.K. Bernstein, L.; Yatani, R.; Henderson, B.E.; Mack, T.M. Cancers of the prostate and breast among Japanese and white immigrants in Los Angeles Country. Br. J. Cancer 1991, 63, 963-966.

4. Wu, A.H.; Ziegler, R.G.; Horn-Ross, P.L.; Nomura, A.M.; West, D.W.; Kolonel, L.N.; Rosenthal, J.F.; Hoover, R.N.; Pike, M.C. Tofu and risk of breast cancer in Asian-Americans. Cancer Epidemiol. Biomark. Prev. 1996, 5, 901-906.

5. Korde, L.A.; Wu, A.H.; Fears, T.; Nomura, A.M.; West, D.W.; Kolonel, L.N.; Pike, M.C.; Hoover, R.N., Ziegler, R.G. Childhood soy intake and breast cancer risk in Asian American women. Cancer Epidemiol. Biomark. Prev. 2009, 18, 1050-1059.

6. Shu, X.O.; Zheng, Y.; Cai, H.; Gu, K.; Chen, Z.; Zheng, W.; Lu, W. Food intake and breast cancer survival. JAMA 2009, 302, 2437-2443. 
7. Messina, M.; Nagata, C.; Wu, A.H. Estimated Asian adult soy protein and isoflavone intakes. Nutr. Cancer 2006, 55, 1-12.

8. Horn-Ross, P.L.; John, E.M.; Lee, M.; Stewart, S.L.; Koo, J.; Sakoda, L.C.; Shiau, A.C.; Goldstein, J.; Davis, P.; Perez-Stable, E.J. Phytoestrogen consumption and breast cancer risk in a multiethnic population: The Bay Area Breast Cancer Study. Am. J. Epidemiol. 2001, 154, 434-441.

9. Lee, H.P.; Gourley, L.; Duffy, S.W.; Esteve, J.; Lee, J.; Day, N.E. Dietary effects on breast-cancer risk in Singapore. Lancet 1991, 337, 1197-1200.

10. Wu, A.H.; Yu, M.C.; Tseng, C.C.; Pike, M.C. Epidemiology of soy exposures and breast cancer risk. Br. J. Cancer 2008, 98, 9-14.

11. Liu, X.O.; Huang, Y.B.; Gao, Y.; Chen, C.; Yan, Y.; Dai, H.J.; Song, F.J.; Wang, Y.G.; Wang, P.S.; Chen, K.X. Association between dietary factors and breast cancer risk among Chinese females: Systematic review and meta-analysis. Asian Pac. J. Cancer Prev. 2014, 15, 1291-1298.

12. Wu, Y.C.; Zheng, D.; Sun, J.J.; Zou, Z.K.; Ma, Z.L. Meta-analysis of studies on breast cancer risk and diet in Chinese women. Int. J. Clin. Exp. Med. 2015, 8, 73-85.

13. Zhu, Y.Y.; Zhou, L.; Jiao, S.C.; Xu, L.Z. Relationship between soy food intake and breast cancer in China. Asian Pac. J. Cancer Prev. 2011, 12, 2837-2840.

14. Dong, J.Y.; Qin, L.Q. Soy isoflavones consumption and risk of breast cancer incidence or recurrence: A meta-analysis of prospective studies. Breast Cancer Res. Treat. 2011, 125, 315-323.

15. Chan, H.Y.; Leung, L.K. A potential protective mechanism of soya isoflavones against 7,12-dimethylbenz[a]anthracene tumour initiation. Br. J. Nutr. 2003, 90, 457-465.

16. Taylor, C.K.; Levy, R.M.; Elliott, J.C.; Burnett, B.P. The effect of genistein aglycone on cancer and cancer risk: A review of in vitro, preclinical, and clinical studies. Nutr. Rev. 2009, 67, 398-415.

17. Valeri, A.; Fiorenzani, P.; Rossi, R.; Aloisi, A.M.; Valoti, M.; Pessina, F. The soy phytoestrogens genistein and daidzein as neuroprotective agents against anoxia-glucopenia and reperfusion damage in rat urinary bladder. Pharmacol. Res. 2012, 66, 309-316.

18. Ko, K.P.; Kim, C.S.; Ahn, Y.; Park, S.J.; Kim, Y.J.; Park, J.K.; Lim, Y.K.; Yoo, K.Y.; Kim, S.S. Plasma isoflavone concentration is associated with decreased risk of type 2 diabetes in Korean women but not men: Results from the Korean Genome and Epidemiology Study. Diabetologia 2015, 58, 726-735.

19. Constantinou, A.I.; Lantvit, D.; Hawthorne, M.; Xu, X.; van Breemen, R.B.; Pezzuto, J.M. Chemopreventive effects of soy protein and purified soy isoflavones on DMBA-induced mammary tumors in female Sprague-Dawley rats. Nutr. Cancer 2001, 41, 75-81.

20. Horie, S. Chemoprevention of prostate cancer: Soy isoflavones and curcumin. Korean J. Urol. 2012, 53, 665-672.

21. Wada, K.; Nakamura, K.; Tamai, Y.; Tsuji, M.; Kawachi, T.; Hori, A.; Takeyama, N.; Tanabashi, S.; Matsushita, S.; Tokimitsu, N.; et al. Soy isoflavone intake and breast cancer risk in Japan: From the Takayama study. Int. J. Cancer 2013, 133, 952-960. 
22. Lim, E.; Metzger-Filho, O.; Winer, E.P. The natural history of hormone receptor-positive breast cancer. Oncology 2012, 26, 688-694.

23. Messina, M.; Hilakivi-Clarke, L. Early intake appears to be the key to the proposed protective effects of soy intake against breast cancer. Nutr. Cancer 2009, 61, 792-798.

24. Dixon, R.A. Phytoestrogens. Annu. Rev. Plant Biol. 2004, 55, 225-261.

25. Hsieh, C.Y.; Santell, R.C.; Haslam, S.Z.; Helferich, W.G. Estrogenic effects of genistein on the growth of estrogen receptor-positive human breast cancer (MCF-7) cells in vitro and in vivo. Cancer Res. 1998, 58, 3833-3838.

26. Zava, D.T.; Duwe, G. Estrogenic and antiproliferative properties of genistein and other flavonoids in human breast cancer cells in vitro. Nutr. Cancer 1997, 27, 31-40.

27. Song, M.; Tian, X.; Lu, M.; Zhang, X.; Ma, K.; Lv, Z.; Wang, Z.; Hu, Y.; Xun, C.; Zhang, Z.; et al. Genistein exerts growth inhibition on human osteosarcoma MG-63 cells via PPAR $\gamma$ pathway. Int. J. Oncol. 2015, doi:10.3892/ijo.2015.2829.

28. Liu, X.; Ye, F.; Wu, J.; How, B.; Li, W.; Zhang, D.Y. Signaling proteins and pathways affected by flavonoids in leukemia cells. Nutr. Cancer 2015, 14, 1-12.

29. Akiyama, T.; Ishida, J.; Nakagawa, S.; Ogawara, H.; Watanabe, S.; Itoh, N.; Shibuya, M.; Fukami, Y. Genistein, a specific inhibitor of tyrosine-specific protein kinases. J. Biol. Chem. 1997, 262, 5592-5595.

30. Mizushina, Y.; Shiomi, K.; Kuriyama, I.; Takahashi, Y.; Yoshida, H. Inhibitory effects of a major soy isoflavone, genistein, on human DNA topoisomerase II activity and cancer cell proliferation. Int. J. Oncol. 2013, 43, 1117-1124.

31. Zhou, N.; Yan, Y.; Li, W.; Wang, Y.; Zheng, L.; Han, S.; Yan, Y.; Li, Y. Genistein inhibition of topoisomerase II $\alpha$ expression participated by Sp1 and Sp3 in HeLa cell. Int. J. Mol. Sci. 2009, 10, 3255-3268.

32. Aggarwal, B.B.; Shishodia, S. Molecular targets of dietary agents for prevention and therapy of cancer. Biochem. Pharmacol. 2006, 71, 1397-1421.

33. Choi, E.J.; Kim, G.H. Daidzein causes cell cycle arrest at the G1 and G2/M phases in human breast cancer MCF-7 and MDA-MB-453 cells. Phytomedicine 2008, 15, 683-690.

34. Choi, Y.H.; Zhang, L.; Lee, W.H.; Park, K.Y. Genistein-induced G2/M arrest is associated with the inhibition of cyclin B1 and the induction of p21 in human breast carcinoma cells. Int. J. Oncol. 1998, 13, 391-396.

35. Sarkar, F.H.; Li, Y. Mechanisms of cancer chemoprevention by soy isoflavone genistein. Cancer Metastasis Rev. 2002, 21, 265-280.

36. Li, Z.; Li, J.; Mo, B.; Hu, C.; Liu, H.; Qi, H.; Wang, X.; Xu, J. Genistein induces cell apoptosis in MDA-MB-231 breast cancer cells via the mitogen-activated protein kinase pathway. Toxicol. In Vitro 2008, 22, 1749-1753.

37. Adams, R.H.; Alitalo, K. Molecular regulation of angiogenesis and lymphangiogenesis. Nat. Rev. Mol. Cell Biol. 2007, 8, 464-478.

38. Bhadada, S.V.; Goyal, B.R.; Patel, M.M. Angiogenic targets for potential disorders. Fundam. Clin. Pharmacol. 2011, 25, 29-47.

39. Hanahan, D.; Folkman, J. Patterns and emerging mechanisms of the angiogenic switch during tumorigenesis. Cell 1996, 86, 353-364. 
40. Folkman, J. Tumor angiogenesis: Therapeutic implications. N. Engl. J. Med. 1971, 285, 1182-1186.

41. Ferrara, N. VEGF as a therapeutic target in cancer. Oncology 2005, 69, 11-16.

42. Claesson-Welsh, L.; Welsh, M. VEGFA and tumour angiogenesis. J. Intern. Med. 2013, 273, 114-127.

43. Wehland, M.; Bauer, J.; Infanger, M.; Grimm, D. Primary tumor cells, stromal cells and cancer stem cells strongly influence vessel growth in tumors. Curr. Pharm. Des. 2012, 18, 4244-4257.

44. Vasudev, N.S.; Reynolds, A.R. Anti-angiogenic therapy for cancer: Current progress, unresolved questions and future directions. Angiogenesis 2014, 17, 471-494.

45. Miller, K.; Wang, M.; Gralow, J.; Dickler, M.; Cobleigh, M.; Perez, E.A.; Shenkier, T.; Cella, D.; Davidson, N.E. Paclitaxel plus bevacizumab vs. paclitaxel alone for metastatic breast cancer. N. Engl. J. Med. 2007, 357, 2666-2676.

46. Miles, D.W.; Chan, A.; Dirix, L.Y.; Cortés, J.; Pivot, X.; Tomczak, P.; Delozier, T.; Sohn, J.H.; Provencher, L.; Puglisi, F.; et al. Phase III study of bevacizumab plus docetaxel compared with placebo plus docetaxel for the first-line treatment of human epidermal growth factor receptor 2-negative metastatic breast cancer. J. Clin. Oncol. 2010, 28, 3239-3247.

47. Robert, N.J.; Saleh, M.N.; Paul, D.; Generali, D.; Gressot, L.; Copur, M.S.; Brufsky, A.M.; Minton, S.E.; Giguere, J.K.; Smith, J.W., 2nd.; et al. Sunitinib plus paclitaxel vs. bevacizumab plus paclitaxel for first-line treatment of patients with advanced breast cancer: A phase III, randomized, open-label trial. Clin. Breast Cancer 2011, 11, 82-92.

48. Brufsky, A.M.; Hurvitz, S.; Perez, E.; Swamy, R.; Valero, V.; O’Neill, V.; Rugo, H.S. RIBBON-2: A randomized, double-blind, placebo-controlled, phase III trial evaluating the efficacy and safety of bevacizumab in combination with chemotherapy for second-line treatment of human epidermal growth factor receptor 2-negative metastatic breast cancer. J. Clin. Oncol. 2011, 29, 4286-4293.

49. Grothey, A.; Flick, E.D.; Cohn, A.L.; Bekaii-Saab, T.S.; Bendell, J.C.; Kozloff, M.; Roach, N.; Mun, Y.; Fish, S.; Hurwitz, H.I. Bevacizumab exposure beyond first disease progression in patients with metastatic colorectal cancer: Analyses of the ARIES observational cohort study. Pharmacoepidemiol. Drug Saf. 2014, 23, 726-734.

50. Grothey, A.; Sugrue, M.M.; Purdie, D.M.; Dong, W.; Sargent, D.; Hedrick, E.; Kozloff, M. Bevacizumab beyond first progression is associated with prolonged overall survival in metastatic colorectal cancer: Results from a large observational cohort study (BRiTE). J. Clin. Oncol. 2008, 26, 5326-5334.

51. Von Minckwitz, G.; Puglisi, F.; Cortes, J.; Vrdoljak, E.; Marschner, N.; Zielinski, C.; Villanueva, C.; Romieu, G.; Lang, I.; Ciruelos, E.; et al. Bevacizumab plus chemotherapy vs. chemotherapy alone as second-line treatment for patients with HER2-negative locally recurrent or metastatic breast cancer after first-line treatment with bevacizumab plus chemotherapy (TANIA): An open-label, randomised phase 3 trial. Lancet Oncol. 2014, 15, 1269-1278. 
52. Gligorov, J.; Doval, D.; Bines, J.; Alba, E.; Cortes, P.; Pierga, J.Y.; Gupta, V.; Costa, R.; Srock, S.; de Ducla, S.; et al. Maintenance capecitabine and bevacizumab vs. bevacizumab alone after initial first-line bevacizumab and docetaxel for patients with HER2-negative metastatic breast cancer (IMELDA): A randomised, open-label, phase 3 trial. Lancet Oncol. 2014, 15, 1351-1360.

53. Robert, N.J.; Diéras, V.; Glaspy, J., Brufsky, A.M.; Bondarenko, I.; Lipatov, O.N.; Perez, E.A.; Yardley, D.A.; Chan, S.Y.; Zhou, X.; et al. RIBBON-1: Randomized, double-blind, placebo-controlled, phase III trial of chemotherapy with or without bevacizumab for first-line treatment of human epidermal growth factor receptor 2-negative, locally recurrent or metastatic breast cancer. J. Clin. Oncol. 2011, 29, 1252-1260.

54. Bergh, J.; Mariani, G.; Cardoso, F.; Liljegren, A.; Awada, A.; Viganò, L.; Huang, X.; Verkh, L.; Kern, K.A.; Giorgetti, C.; et al. Clinical and pharmacokinetic study of sunitinib and docetaxel in women with advanced breast cancer. Breast 2012, 21, 507-513.

55. Crown, J.P.; Diéras, V.; Staroslawska, E.; Yardley, D.A.; Bachelot, T.; Davidson, N.; Wildiers, H.; Fasching, P.A.; Capitain, O.; Ramos, M.; et al. Phase III trial of sunitinib in combination with capecitabine vs. capecitabine monotherapy for the treatment of patients with pretreated metastatic breast cancer. J. Clin. Oncol. 2013, 31, 2870-2878.

56. Sun, M.; Larcher, A.; Karakiewicz, P.I. Optimal first-line and second-line treatments for metastatic renal cell carcinoma: Current evidence. Int. J. Nephrol. Renovasc. Dis. 2014, 29, 401-407.

57. Piccart, M.; Hortobagyi, G.N.; Campone, M.; Pritchard, K.I.; Lebrun, F.; Ito, Y.; Noguchi, S.; Perez, A.; Rugo, H.S.; Deleu, I.; et al. Everolimus plus exemestane for hormone-receptor-positive, human epidermal growth factor receptor-2-negative advanced breast cancer: Overall survival results from BOLERO-2. Ann. Oncol. 2014, 25, 2357-2362.

58. Chen, J.; Yao, Q.; Li, D.; Zhang, J.; Wang, T.; Yu, M.; Zhou, X.; Huan, Y.; Wang, J.; Wang, L. Neoadjuvant rh-endostatin, docetaxel and epirubicin for breast cancer: Efficacy and safety in a prospective, randomized, phase II study. BMC Cancer 2013, 21, 248.

59. Yang, F.; Zhang, W.; Shen, Y.; Guan, X. Identification of dysregulated microRNAs in triple-negative breast cancer (Review). Int. J. Oncol. 2015, doi:10.3892/ijo.2015.2821.

60. Calixto, J.B. Efficacy, safety, quality control, marketing and regulatory guidelines for herbal medicines (phytotherapeutic agents). Braz. J. Med. Biol. Res. 2000, 33, 179-189.

61. Bear, H.D.; Tang, G.; Rastogi, P.; Geyer, C.E., Jr.; Robidoux, A.; Atkins, J.N.; Baez-Diaz, L.; Brufsky, A.M.; Mehta, R.S.; Fehrenbacher, L.; et al. Bevacizumab added to neoadjuvant chemotherapy for breast cancer. N. Engl. J. Med. 2012, 366, 310-320.

62. Von Minckwitz, G.; Eidtmann, H.; Rezai, M.; Fasching, P.A.; Tesch, H.; Eggemann, H.; Schrader, I.; Kittel, K.; Hanusch, C.; Kreienberg, R.; et al. Neoadjuvant chemotherapy and bevacizumab for HER2-negative breast cancer. N. Engl. J. Med. 2012, 366, 299-309.

63. Von Minckwitz, G.; Loibl, S.; Untch, M.; Eidtmann, H.; Rezai, M.; Fasching, P.A.; Tesch, H.; Eggemann, H.; Schrader, I.; Kittel, K.; et al. Survival after neoadjuvant chemotherapy with or without bevacizumab or everolimus for HER2-negative primary breast cancer (GBG 44-GeparQuinto)†. Ann. Oncol. 2014, 25, 2363-2372. 
64. Cameron, D.; Brown, J.; Dent, R.; Jackisch, C.; Mackey, J.; Pivot, X.; Steger, G.G.; Suter, T.M.; Toi, M.; Parmar, M.; et al. Adjuvant bevacizumab-containing therapy in triple-negative breast cancer (BEATRICE): Primary results of a randomised, phase 3 trial. Lancet Oncol. 2013, 14, 933-942.

65. Gianni, L.; Romieu, G.H.; Lichinitser, M.; Serrano, S.V.; Mansutti, M.; Pivot, X.; Mariani, P.; Andre, F.; Chan, A.; Lipatov, O.; et al. AVEREL: A randomized phase III Trial evaluating bevacizumab in combination with docetaxel and trastuzumab as first-line therapy for HER2-positive locally recurrent/metastatic breast cancer. J. Clin. Oncol. 2013, 31, 1719-1725.

66. Baselga, J.; Costa, F.; Gomez, H.; Hudis, C.A.; Rapoport, B.; Roche, H.; Schwartzberg, L.S.; Petrenciuc, O.; Shan, M.; Gradishar, W.J. A phase 3 trial comparing capecitabine in combination with Sorafenib or placebo for treatment of locally advanced or metastatic HER2-negative breast cancer (the RESILIENCE study): Study protocol for a randomized controlled trial. Trials 2013, $14,228$.

67. Miller, K.D.; Chap, L.I.; Holmes, F.A.; Cobleigh, M.A.; Marcom, P.K.; Fehrenbacher, L.; Dickler, M.; Overmoyer, B.A.; Reimann, J.D.; Sing, A.P.; et al. Randomized phase III trial of capecitabine compared with bevacizumab plus capecitabine in patients with previously treated metastatic breast cancer. J. Clin. Oncol. 2005, 23, 792-799.

68. André, F.; O’Regan, R.; Ozguroglu, M.; Toi, M.; Xu, B.; Jerusalem, G.; Masuda, N.; Wilks, S.; Arena, F.; Isaacs, C.; et al. Everolimus for women with trastuzumab-resistant, HER2-positive, advanced breast cancer (BOLERO-3): A randomised, double-blind, placebo-controlled phase 3 trial. Lancet Oncol. 2014, 15, 580-591.

69. Barrios, C.H.; Liu, M.C.; Lee, S.C.; Vanlemmens, L.; Ferrero, J.M.; Tabei, T.; Pivot, X.; Iwata, H.; Aogi, K.; Lugo-Quintana, R.; et al. Phase III randomized trial of sunitinib vs. capecitabine in patients with previously treated HER2-negative advanced breast cancer. Breast Cancer Res. Treat. 2010, 121, 121-131.

70. Nishida, N.; Yano, H.; Nishida, T.; Kamura, T.; Kojiro, M. Angiogenesis in cancer. Vasc. Health Risk Manag. 2006, 2, 213-219.

71. Mojzis, J.; Varinska, L.; Mojzisova, G.; Kostova, I.; Mirossay, L. Antiangiogenic effects of flavonoids and chalcones. Pharmacol. Res. 2008, 57, 259-265.

72. Pilátová, M.; Stupáková, V.; Varinská, L.; Sarisský, M.; Mirossay, L.; Mirossay, A.; Gál, P.; Kraus, V.; Dianisková, K.; Mojzis, J. Effect of selected flavones on cancer and endothelial cells. Gen. Physiol. Biophys. 2010, 29, 134-143.

73. Kumazawa, S.; Kubota, S.; Yamamoto, H.; Okamura, N.; Sugiyamab, Y.; Kobayashia, H.; Nakanishi, M.; Ohta, T. Antiangiogenic activity of flavonoids from Melia azedarach. Nat. Prod. Commun. 2013, 8, 1719-1720.

74. Zhang, M.; Liu, C.; Zhang, Z.; Yang, S.; Zhang, B.; Yin, L.; Swarts, S.; Vidyasagar, S.; Zhang, L.; Okunieff, P. A new flavonoid regulates angiogenesis and reactive oxygen species production. Adv. Exp. Med. Biol. 2014, 812, 149-155.

75. Ivanova, L.; Varinska, L.; Pilatova, M.; Gal, P.; Solar, P.; Perjesi, P.; Smetana, K., Jr.; Ostro, A.; Mojzis, J. Cyclic chalcone analogue KRP6 as a potent modulator of cell proliferation: An in vitro study in HUVECs. Mol. Biol. Rep. 2013, 40, 4571-4580. 
76. Varinska, L.; van Wijhe, M.; Belleri, M.; Mitola, S.; Perjesi, P.; Presta, M.; Koolwijk, P.; Ivanova, L.; Mojzis, J. Anti-angiogenic activity of the flavonoid precursor 4-hydroxychalcone. Eur. J. Pharmacol. 2012, 691, 125-133.

77. Pilatova, M.; Varinska, L.; Perjesi, P.; Sarissky, M.; Mirossay, L.; Solar, P.; Ostro, A.; Mojzis, J. In vitro antiproliferative and antiangiogenic effects of synthetic chalcone analogues. Toxicol. In Vitro 2010, 24, 1347-1355.

78. Mojzis, J.; Sarisský, M.; Pilátová, M.; Voharová, V.; Varinská, L.; Mojzisová, G.; Ostro, A.; Urdzík, P.; Dankovcik, R.; Mirossay, L. In vitro antiproliferative and antiangiogenic effects of Flavin7. Physiol. Res. 2008, 57, 413-420.

79. Fotsis, T.; Pepper, M.; Adlercreutz, H.; Fleischmann, G.; Hase, T.; Montesano, R.; Schweigerer, L. Genistein, a dietary-derived inhibitor of in vitro angiogenesis. Proc. Natl. Acad. Sci. USA 1993, 90, 2690-2694.

80. Fotsis, T.; Pepper, M.; Adlercreutz, H.; Hase, T.; Montesano, R.; Schweigerer, L. Genistein, a dietary ingested isoflavonoid, inhibits cell proliferation and in vitro angiogenesis. J. Nutr. 1995, $125,790-797$.

81. Nagaraju, G.P.; Zafar, S.F.; el-Rayes, B.F. Pleiotropic effects of genistein in metabolic, inflammatory, and malignant diseases. Nutr. Rev. 2013, 71, 562-572.

82. Gacche, R.N.; Meshram, R.J. Angiogenic factors as potential drug target: Efficacy and limitations of anti-angiogenic therapy. Biochim. Biophys. Acta 2014, 1846, 161-179.

83. Guo, Y.; Wang, S.; Hoot, D.R.; Clinton, S.K. Suppression of VEGF-mediated autocrine and paracrine interactions between prostate cancer cells and vascular endothelial cells by soy isoflavones. J. Nutr. Biochem. 2007, 18, 408-417.

84. Levy, A.P.; Levy, N.S.; Goldberg, M.A. Post-transcriptional regulation of vascular endothelial growth factor by hypoxia. J. Biol. Chem. 1996, 271, 2746-2753.

85. Yu, X.; Mi, M.; Zhu, J. Genistein inhibits the expression of vascular endothelial growth factor in MDA-MB-453 breast cancer cells. U.S. Chin. J. Lymphol. Oncol. 2008, 7, 8-13.

86. Su, S.J.; Yeh, T.M.; Chuang, W.J.; Ho, C.L.; Chang, K.L.; Cheng, H.L.; Liu, H.S.; Cheng, H.L.; Hsu, P.Y.; Chow, N.H. The novel targets for anti-angiogenesis of genistein on human cancer cells. Biochem. Pharmacol. 2005, 69, 307-318.

87. Büchler, P.; Reber, H.A.; Büchler, M.W.; Friess, H.; Lavey, R.S.; Hines, O.J. Antiangiogenic activity of genistein in pancreatic carcinoma cells is mediated by the inhibition of hypoxia-inducible factor-1 and the down-regulation of VEGF gene expression. Cancer 2004, 100, 201-210.

88. Aditya, N.P.; Shim, M.; Yang, H.; Lee, Y.J.; Ko, S. Antiangiogenic effect of combined treatment with curcumin and genistein on human prostate cancer cell line. J. Funct. Food 2014, 8, 204-213.

89. Ambra, R.; Rimbach, G.; de Pascual Teresa, S.; Fuchs, D.; Wenzel, U.; Daniel, H.; Virgili, F. Genistein affects the expression of genes involved in blood pressure regulation and angiogenesis in primary human endothelial cells. Nutr. Metab. Cardiovasc. Dis. 2006, 16, 35-43.

90. Zhou, J.R.; Gugger, E.T.; Tanaka, T.; Guo, Y.; Blackburn, G.L.; Clinton, S.K. Soybean phytochemicals inhibit the growth of transplantable human prostate carcinoma and tumor angiogenesis in mice. J. Nutr. 1999, 129, 1628-1635. 
91. Bakkiyanathan, A.; Joseph, A.M.; Tharani, L.; Malathi, R. Genistein, the phytoestrogen induces heart-and-soul (has) phenotypes in zebrafish embryo. J. Dev. Biol. Tissue Eng. 2010, 2, 18-22.

92. Mukhopadhyay, S.; Ballard, B.R.; Mukherjee, S.; Kabir, S.M.; Das, S.K. Beneficial effects of soy protein in the initiation and progression against dimethylbenz(a) anthracene-induced breast tumors in female rats. Mol. Cell. Biochem. 2006, 290, 169-176.

93. Hennet, T. Diseases of glycosylation. In The Sugar Code: Fundamentals of Glycosciences; Gabius, H.-J., Ed.; Wiley-VCH: Weinheim, Germany, 2009; pp. 365-383.

94. Honke, K.; Taniguchi, N. Animal models to delineate glycan functionality. In The Sugar Code. Fundamentals of Glycosciences; Gabius, H.-J., Ed.; Wiley-VCH: Weinheim, Germany, 2009; pp. 385-401.

95. Nyberg, P.; Salo, T.; Kalluri, R. Tumor microenvironment and angiogenesis. Front. Biosci. 2008, 13, 6537-6553.

96. Rabbani, S.A.; Mazar, A.P. The role of the plasminogen activation system in angiogenesis and metastasis. Surg. Oncol. Clin. N. Am. 2001, 10, 393-415.

97. Rundhaug, J.E. Matrix metalloproteinases and angiogenesis. J. Cell Mol. Med. 2005, 9, 267-285.

98. Hadler-Olsen, E.; Winberg, J.O.; Uhlin-Hansen, L. Matrix metalloproteinases in cancer: Their value as diagnostic and prognostic markers and therapeutic targets. Tumour Biol. 2013, 34, 2041-2051.

99. Kim, M.H. Flavonoids inhibit VEGF/bFGF-induced angiogenesis in vitro by inhibiting the matrix-degrading proteases. J. Cell. Biochem. 2003, 89, 529-538.

100. Kumi-Diaka, J.K.; Hassanhi, M.; Merchant, K.; Horman, V. Influence of genistein isoflavone on matrix metalloproteinase-2 expression in prostate cancer cells. J. Med. Food 2006, 9, 491-497.

101. Latocha, M.; Płonka, J.; Kuśmierz, D.; Jurzak, M.; Polaniak, R.; Nowosad, A. Transcripional activity of genes encoding MMPS and TIMPs in breast cancer cells treated by genistein and in normal cancer-associated fibroblasts ñ in vitro studies. Acta Pol. Pharm. Drug Res. 2014, 71, 1095-1102.

102. Farina, H.G.; Pomies, M.; Alonso, D.F.; Gomez, D.E. Antitumor and antiangiogenic activity of soy isoflavone genistein in mouse models of melanoma and breast cancer. Oncol. Rep. 2006, 16, 885-891.

103. Piao, M.; Mori, D.; Satoh, T.; Sugita, Y.; Tokunaga, O. Inhibition of endothelial cell proliferation, in vitro angiogenesis, and the down-regulation of cell adhesion-related genes by genistein. Combined with a cDNA microarray analysis. Endothelium 2006, 13, 249-266.

104. Rabiau, N.; Kossaï, M.; Braud, M.; Chalabi, N.; Satih, S.; Bignon, Y.J.; Bernard-Gallon, D.J. Genistein and daidzein act on a panel of genes implicated in cell cycle and angiogenesis by polymerase chain reaction arrays in human prostate cancer cell lines. Cancer Epidemiol. 2010, 34, 200-206.

105. Li, Y.; Sarkar, F.H. Down-regulation of invasion and angiogenesis-related genes identified by cDNA microarray analysis of PC3 prostate cancer cells treated with genistein. Cancer Lett. 2002, $186,157-164$. 
106. Handayani, R.; Rice, L.; Cui, Y.; Medrano, T.A.; Samedi, V.G.; Baker, H.V.; Szabo, N.J.; Shiverick, K.T. Soy isoflavones alter expression of genes associated with cancer progression, including interleukin-8, in androgen-independent PC-3 human prostate cancer cells. J. Nutr. 2006, 136, 75-82.

107. Sarkar, F.H.; Li, Y.; Wang, Z.; Kong, D. Cellular signaling perturbation by natural products. Cell Signal. 2009, 21, 1541-1547.

108. Shishodia, S.; Aggarwal, B.B. Nuclear factor-кB activation mediates cellular transformation, proliferation, invasion angiogenesis and metastasis of cancer. Cancer Treat. Res. 2004, 119, $139-173$.

109. Wang, S.D.; Chen, B.C.; Kao, S.T.; Liu, C.J.; Yeh, C.C. Genistein inhibits tumor invasion by suppressing multiple signal transduction pathways in human hepatocellular carcinoma cells. BMC Complement. Altern. Med. 2014, 14, doi:10.1186/1472-6882-14-26.

110. Wang, J.; Eltoum, I.E.; Lamartiniere, C.A. Genistein alters growth factor signaling in transgenic prostate model (TRAMP). Mol. Cell. Endocrinol. 2004, 219, 171-180.

111. Yu, X.; Zhu, J.; Mi, M.; Chen, W.; Pan, Q.; Wei, M. Anti-angiogenic genistein inhibits VEGF-induced endothelial cell activation by decreasing PTK activity and MAPK activation. Med. Oncol. 2012, 29, 349-357.

112. Huang, X.; Chen, S.; Xu, L.; Liu, Y.; Deb, D.K.; Platanias, L.C.; Bergan, R.C. Genistein inhibits p38 map kinase activation, matrix metalloproteinase type 2, and cell invasion in human prostate epithelial cells. Cancer Res. 2005, 65, 3470-3478.

113. Xu, L.; Bergan, R.C. Genistein inhibits matrix metalloproteinase type 2 activation and prostate cancer cell invasion by blocking the transforming growth factor $\beta$-mediated activation of mitogen-activated protein kinase-activated protein kinase $2-27-\mathrm{kDa}$ heat shock protein pathway. Mol. Pharmacol. 2006, 70, 869-877.

114. Chang, W.S.; Liao, C.H.; Miao, C.E.; Wu, H.C.; Hou, L.L.; Hsiao, C.L.; Ji, H.X.; Tsai, C.W.; Bau, D.T. The role of functional polymorphisms of cyclooxygenase 2 in renal cell carcinoma. Anticancer Res. 2014, 34, 5481-5486.

115. Kisková, T.; Jendželovský, R.; Rentsen, E.; Maier-Salamon, A.; Kokošová, N.; Papčová, Z.; Mikeš, J.; Orendáš, P.; Bojková, B.; Kubatka, P.; et al. Resveratrol enhances the chemopreventive effect of celecoxib in chemically induced breast cancer in rats. Eur. J. Cancer Prev. 2014, 23, 506-513.

116. Iñiguez, M.A.; Rodríguez, A.; Volpert, O.V.; Fresno, M.; Redondo, J.M. Cyclooxygenase-2: A therapeutic target in angiogenesis. Trends Mol. Med. 2003, 9, 73-78.

117. Salvado, M.D.; Alfranca, A.; Haeggström, J.Z.; Redondo, J.M. Prostanoids in tumor angiogenesis: Therapeutic intervention beyond COX-2. Trends Mol. Med. 2012, 18, 233-243.

118. Toomey, D.P.; Murphy, J.F.; Conlon, K.C. COX-2, VEGF and tumour angiogenesis. Surgeon 2009, 7, 174-180.

119. Majima, M.; Hayashi, I.; Muramatsu, M.; Katada, J.; Yamashina, S.; Katori, M. Cyclo-oxygenase-2 enhances basic fibroblast growth factor-induced angiogenesis through induction of vascular endothelial growth factor in rat sponge implants. Br. J. Pharmacol. 2000, 130, 641-649. 
120. Akarasereenont, P.C.; Techatraisak, K.; Thaworn, A.; Chotewuttakorn, S. The expression of COX-2 in VEGF-treated endothelial cells is mediated through protein tyrosine kinase. Mediat. Inflamm. 2002, 11, 17-22.

121. Balkwill, F.R.; Mantovani, A. Cancer-related inflammation: Common themes and therapeutic opportunities. Semin. Cancer Biol. 2012, 22, 33-40.

122. Mantovani, A.; Allavena, P.; Sica, A.; Balkwill, F. Cancer-related inflammation. Nature 2008, 454, 436-444.

123. Candido, J.; Hagemann, T. Cancer-related inflammation. J. Clin. Immunol. 2013, 33, 79-84.

124. Taketo, M.M. Cyclooxygenase-2 inhibitors in tumorigenesis (Part II). J. Natl. Cancer Inst. 1998, 90, 1609-1620.

125. Masmoudi, A.; le Chevalier, T.; Sabatier, L.; Soria, J.C. Cyclooxygenase 2 inhibitors and cancer chemoprevention. Bull. Cancer 2004, 91, 77-84.

126. Cooper, K.; Squires, H.; Carroll, C.; Papaioannou, D.; Booth, A.; Logan, R.F.; Maguire, C.; Hind, D.; Tappenden, P. Chemoprevention of colorectal cancer: Systematic review and economic evaluation. Health Technol. Assess. 2010, 14, 1-206.

127. Hwang, J.T.; Lee, Y.K.; Shin, J.I.; Park, O.J. Anti-inflammatory and anticarcinogenic effect of genistein alone or in combination with capsaicin in TPA-treated rat mammary glands or mammary cancer cell line. Ann. N. Y. Acad. Sci. 2009, 1171, 415-420.

128. Chung, M.H.; Kim, D.H.; Na, H.K.; Kim, J.H.; Kim, H.N.; Haegeman, G.; Surh, Y.J. Genistein inhibits phorbol ester-induced NF- $\mathrm{BB}$ transcriptional activity and COX-2 expression by blocking the phosphorylation of p65/Rel in human mammary epithelial cells. Mutat. Res. Fundam. Mol. Mech. Mutagen. 2014, 768, 74-83.

129. Li, Y.S.; Wu, L.P.; Li, K.H.; Liu, Y.P.; Xiang, R.; Zhang, S.B.; Zhu, L.Y.; Zhang, L.Y. Involvement of nuclear factor $\kappa \mathrm{B}(\mathrm{NF}-\kappa \mathrm{B})$ in the downregulation of cyclooxygenase-2 (COX-2) by genistein in gastric cancer cells. J. Int. Med. Res. 2011, 39, 2141-2150.

130. Khan, A.Q.; Khan, R.; Rehman, M.U.; Lateef, A.; Tahir, M.; Ali, F.; Sultana, S. Soy isoflavones (daidzein \& genistein) inhibit 12-O-tetradecanoylphorbol-13-acetate (TPA)-induced cutaneous inflammation via modulation of COX-2 and NF- $\mathrm{KB}$ in Swiss albino mice. Toxicology 2012, 302, 266-274.

131. Polverini, P.J.; Leibovich, S.J. Induction of neovascularization in vivo and endothelial proliferation in vitro by tumor-associated macrophages. Lab. Investig. 1984, 51, 635-642.

132. Solinas, G.; Germano, G.; Mantovani, A.; Allavena, P. Tumor-associated macrophages (TAM) as major players of the cancer-related inflammation. J. Leukoc. Biol. 2009, 86, 1065-1073.

133. Chanmee, T.; Ontong, P.; Konno, K.; Itano, N. Tumor-associated macrophages as major players in the tumor microenvironment. Cancers 2014, 6, 1670-1690.

134. Chen, X.; Zhang, L.; Zhang, I.Y.; Liang, J.; Wang, H.; Ouyang, M.; Wu, S.; da Fonseca, A.C.; Weng, L.; Yamamoto, Y.; et al. RAGE expression in tumor-associated macrophages promotes angiogenesis in glioma. Cancer Res. 2014, 74, 7285-7297.

135. Bingle, L.; Lewis, C.E.; Corke, K.P.; Reed, M.W.; Brown, N.J. Macrophages promote angiogenesis in human breast tumour spheroids in vivo. Br. J. Cancer 2006, 94, 101-107.

136. Joseph, I.B.; Isaacs, J.T. Macrophage role in the anti-prostate cancer response to one class of antiangiogenic agents. J. Natl. Cancer Inst. 1998, 90, 1648-1653. 
137. Lee, S.H.; Lee, J.; Jung, M.H.; Lee, Y.M. Glyceollins, a novel class of soy phytoalexins, inhibit angiogenesis by blocking the VEGF and bFGF signaling pathways. Mol. Nutr. Food Res. 2013, $57,225-234$.

138. Lee, S.H.; Jee, J.G.; Bae, J.S.; Liu, K.H.; Lee, Y.M. A group of novel HIF-1 $\alpha$ inhibitors, Glyceollins, Blocks HIF-1 $\alpha$ Synthesis and Decreases Its Stability via Inhibition of the PI3K/AKT/mTOR Pathway and Hsp90 Binding. J. Cell. Physiol. 2015, 230, 853-862.

139. Kim, H.J.; Sung, M.K.; Kim, J.S. Anti-inflammatory effects of glyceollins derived from soybean by elicitation with Aspergillus sojae. Inflamm. Res. 2011, 60, 909-917.

140. Gabius, H.J.; André, S.; Jiménez-Barbero, J.; Romero, A.; Solís, D. From lectin structure to functional glycomics: Principles of the sugar code. Trends Biochem. Sci. 2011, 36, 298-313.

141. Gabius, H.J.; Siebert, H.C.; André, S.; Jiménez-Barbero, J.; Rüdiger, H. Chemical biology of the sugar code. Chem. Biol. Chem. 2004, 5, 740-764.

142. Dvořánková, B.; Szabo, P.; Lacina, L.; Gal, P.; Uhrova, J.; Zima, T.; Kaltner, H.; André, S.; Gabius, H.J.; Sykova, E.; et al. Human galectins induce conversion of dermal fibroblasts into myofibroblasts and production of extracellular matrix: Potential application in tissue engineering and wound repair. Cells Tissues Organs 2011, 194, 469-480.

143. Klíma, J.; Lacina, L.; Dvoránková, B.; Herrmann, D.; Carnwath, J.W.; Niemann, H.; Kaltner, H.; André, S.; Motlík, J.; Gabius, H.J.; et al. Differential regulation of galectin expression/reactivity during wound healing in porcine skin and in cultures of epidermal cells with functional impact on migration. Physiol. Res. 2009, 58, 873-884.

144. Smetana, K., Jr.; Szabo, P.; Gal, P.; André, S.; Gabius, H.J.; Kodet, O.; Dvořánková, B. Emerging role of tissue lectins as microenvironmental effectors in tumors and wounds. Histol. Histopathol. 2015, 30, 293-309.

145. Dalotto-Moreno, T.; Croci, D.O.; Cerliani, J.P.; Martinez-Allo, V.C.; Dergan-Dylon, S.; Méndez-Huergo, S.P.; Stupirski, J.C.; Mazal, D.; Osinaga, E.; Toscano, M.A.; et al. Targeting galectin-1 overcomes breast cancer-associated immunosuppression and prevents metastatic disease. Cancer Res. 2013, 73, 1107-1117.

146. Ito, K.; Stannard, K.; Gabutero, E.; Clark, A.M.; Neo, S.Y.; Onturk, S.; Blanchard, H.; Ralph, S.J. Galectin-1 as a potent target for cancer therapy: Role in the tumor microenvironment. Cancer Metastasis Rev. 2012, 31, 763-778.

147. Hsieh, S.H.; Ying, N.W.; Wu, M.H.; Chiang, W.F.; Hsu, C.L.; Wong, T.Y.; Jin, Y.T.; Hong, T.M.; Chen, Y.L. Galectin-1, a novel ligand of neuropilin-1, activates VEGFR-2 signaling and modulates the migration of vascular endothelial cells. Oncogene 2008, 27, 3746-3753.

148. Moisa, A.; Fritz, P.; Eck, A.; Wehner, H.D.; Mürdter, T.; Simon, W.; Gabius, H.J. Growth/adhesion-regulatory tissue lectin galectin-3: Stromal presence but not cytoplasmic/ nuclear expression in tumor cells as a negative prognostic factor in breast cancer. Anticancer Res. 2007, 27, 2131-2139.

149. Rêgo, M.J.; da Silva Filho, A.F.; Cordeiro, M.F.; Santos, P.B.; Beltrão, E.I. The glycomic profile of invasive ductal carcinoma of the breast is altered in patients with hypoxic regions: Implications for tumor behavior. Folia Histochem. Cytobiol. 2014, 52, 96-103.

150. Markowska, A.; Liu, F.T.; Panjwani, N. Galectin-3 is an important mediator of VEGF- and bFGF-mediated angiogenic response. J. Exp. Med. 2010, 207, 1981-1993. 
151. Shon, Y.H.; Park, S.D.; Nam, K.S. Effective chemopreventive activity of genistein against human breast cancer cells. J. Biochem. Mol. Biol. 2006, 39, 448-451.

152. Jung, E.J.; Moon, H.G.; Cho, B.I.; Jeong, C.Y.; Joo, Y.T.; Lee, Y.J.; Hong, S.C.; Choi, S.K.; Ha, W.S.; Kim, J.W.; et al. Galectin-1 expression in cancer-associated stromal cells correlates tumor invasiveness and tumor progression in breast cancer. Int. J. Cancer 2007, 120, 2331-2338.

153. Fuchs, D.; Vafeiadou, K.; Hall, W.L.; Daniel, H.; Williams, C.M.; Schroot, J.H.; Wenzel, U. Proteomic biomarkers of peripheral blood mononuclear cells obtained from postmenopausal women undergoing an intervention with soy isoflavones. Am. J. Clin. Nutr. 2007, 86, 1369-1375.

154. Santen, R.J.; Song, R.X.; Zhang, Z.; Kumar, R.; Jeng, M.H.; Masamura, A.; Lawrence, J., Jr.; Berstein, L.; Yue, W. Long-term estradiol deprivation in breast cancer cells up-regulates growth factor signaling and enhances estrogen sensitivity. Endocr. Relat. Cancer 2005, 12, 61-73.

155. Lin, H.M.; Moon, B.K.; Yu, F.; Kim, H.R. Galectin-3 mediates genistein-induced $\mathrm{G}_{2} / \mathrm{M}$ arrest and inhibits apoptosis. Carcinogenesis 2000, 21, 1941-1945.

156. Shimura, T.; Takenaka, Y.; Fukumori, T.; Tsutsumi, S.; Okada, K.; Hogan, V.; Kikuchi, A.; Kuwano, H.; Raz, A. Implication of galectin-3 in Wnt signaling. Cancer Res. 2005, 65, 3535-3537.

157. Wang, H.; Charles, P.C.; Wu, Y.; Ren, R.; Pi, X.; Moser, M.; Barshishat-Kupper, M.; Rubin, J.S.; Perou, C.; Bautch, V.; et al. Gene expression profile signatures indicate a role for Wnt signaling in endothelial commitment from embryonic stem cells. Circ. Res. 2006, 98, 1331-1339.

158. Andrade, J.E.; Ju, Y.H.; Baker, C.; Doerge, D.R.; Helferich, W.G. Long-term exposure to dietary sources of genistein induces estrogen-independence in the human breast cancer (MCF-7) xenograft model. Mol. Nutr. Food Res. 2014, doi:10.1002/mnfr.201300780.

(C) 2015 by the authors; licensee MDPI, Basel, Switzerland. This article is an open access article distributed under the terms and conditions of the Creative Commons Attribution license (http://creativecommons.org/licenses/by/4.0/). 